\title{
Aerospace Clusters and Competitiveness Poles: A France-Quebec Comparison
}

\author{
Nathalie Gardes ${ }^{1}$, Isabelle Dostaler ${ }^{2}$, Céline Barredy $^{3}$ and Corinne Gourmel-Rouger ${ }^{1}$ \\ 1. IRGO (Institut de Recherche en Gestion des Organisations; Organizational Management Research Institute), University of \\ Bordeaux, Bordeaux 33072, France \\ 2. John Molson School of Business, University of Concordia, Quebec H3G 1M8, Canada \\ 3. CEROS (Centre d'Etudes et de Recherches sur les Organisations et la Stratégie; Center for Research on Organizations and \\ Strategy), University of Paris Ouest Nanterre La Défense, Nanterre 92001, France
}

\begin{abstract}
Aerospace product development and manufacturing are key components of the air transport system. At national levels in developed countries, the aerospace industry is considered as a highly strategic sector. A solid national aerospace industry is therefore a symbol of strength. Countries are pragmatic: the positive impact of a well-developed transportation network on economic growth is indubitable and civil aircraft production is a key element of this network. Countries may also assert their sovereignty by being recognized players in the defence segment of aerospace. This paper will look at the cases of France and Quebec where local governments have invested significant public funding in poles of competitiveness (in the case of France) and clusters (in the case of Quebec). While our examination of the France and Quebec aerospace scenes reveals a surprisingly large number of groupings, it does not indicate that all their members, large and small, equally benefit from participating in them. In this thick institutional environment, aerospace clusters and poles of competitiveness may compete against each other and become self-serving rather than representing and promoting their members.
\end{abstract}

Key words: Competitiveness, clusters, aerospace industry, network.

\section{Introduction}

It is remarkable that the aerospace sector, in which dynamics are highly globalized, specifically emphasizes spatial groupings most often in the shape of poles or clusters embedded in average size cities local environment like Montreal, Seattle, Toronto, Toulouse [1] and Bordeaux. In this paper, we focus on two specific regions, France and Quebec, and look at how aerospace clusters and competitive poles have developed in these two territories. The objective of the research is to identify similarities between France and Quebec aerospace policies to evaluate the extent to which networks that are created somewhat artificially can truly favor economic development and provide equal business opportunities to all aerospace players,

Corresponding author: Nathalie Gardes, Ph.D., associate professor, research fields: management and finance. E-mail: nath.gardes@gmail.com. large and small.

According to Alfonso-Gil et al. [2], the aerospace industry was characterized initially and historically by small firms specialized in precision work, often done by hand. A movement towards industrialization and clusterization in the field started in the 1980s. The crisis of Fordism that took place forced a renewal of the production model, focusing on territory exploitation, highlighting the role of industry players and the imperativeness of flexibility. Companies were therefore pushed to connect, develop networks, create and maintain their competitive advantages through territorialized processes [3]. According to Porter [4], when competition is global, the essential sources of competitive advantages will often be local and will be based on critical masses of highly specialized and interlinked competencies, applied technologies, firms, suppliers as well as localized institutions. Therefore, 
the local territory appears like a privileged area of relationships between players $[5,6]$.

This paper will present a review of the most important aerospace groupings in Quebec, one of the 10 provinces of Canada, and in France, where local governments have allocated significant public funding to poles of competitiveness and clusters. In addition to comparable aerospace policies, France and Quebec are two francophone territories sharing deep historical roots as Quebec was once a French colony. As we will see, the aerospace groupings that can be found in France and in Quebec significantly depart from the more organic agglomeration of firms defined as Marshallian industrial districts which naturally favor the development of social capital [7-9]. Our study leads us to questioning the extent to which willful policy makers can indeed create networks genuinely favoring the development of social capital and providing equal access to resources to all of the members of the network. Furthermore, the spectacular expansion of competitiveness poles in recent years in France and the considerable amount of financial resources invested in them lead us to wondering about the real impact of these public initiatives on aerospace firms' financial and strategic performance.

\section{France and Canada: Two "Traditional" Aerospace Players}

The global aerospace industry consists of two large categories: civil aerospace and defence. The primary companies at the top of the aerospace supply chain are a relatively small number of OEMs (original equipment manufacturers) that produce the whole aircraft architecture and do the systems integration. A number of structural changes have taken place along the global aerospace supply chain through the years, as first tier suppliers have become risk partners who are required to invest in the development and manufacturing of large aircraft subassemblies. Risk partnerships have clear financial advantages because they allow aerospace OEMs to invest less capital into new programs, thus incurring less risk on each project. However, they also have serious downsides, including home country job-losses.

Unsurprisingly, the United States ranked first in 2010 in terms of manufacturing revenue, followed by France, Germany, the UK and Canada [10]. These countries are considered as "traditional" aerospace players, as opposed to "newer or emergent" players such as Japan, Brazil, Mexico, China and India or "re-emerging” players such as Russia. A number of threats exist in the general environment in which aerospace players operate. Growing environmental awareness and increased security measures could have negative impacts on the demand for air travel, and consequently, on aircraft orders. The state of affairs in the airline industry, in particular the volatile fuel prices, also has a significant impact on the aerospace competitive environment. Air carriers have become extremely cost-sensitive and commercial airplanes have moved from a differentiated market toward a price-sensitive commodity market.

The French aerospace industry is undeniably powerful on the global stage. Ranked second in the world in terms of manufacturing revenue behind the United States [10], French annual aerospace sales amounted to US $\$ 66.2$ billion in $2013^{1}$. That amount makes up for just over $2.42 \%$ of the nation's GDP (gross domestic product), the highest percentage of any of the top aerospace manufacturing countries ${ }^{2}$. In 2008, France exported a significant $75 \%$ of its aerospace production to countries around the world for a rough total of $\$ 49.7$ billion in exported sales ${ }^{3}$. This amount of exports gives the country a surplus in the industry.

Airbus Group is the leader of civil aircraft manufacturing around the world, making a 2013

\footnotetext{
${ }^{1}$ http://www.defensenews.com/article/20140428/DEFREG01/30 4280023/Lahoud-Civil-Aerospace-Sales-Continue-Outstrip-Mil itary-Side.

${ }^{2}$ http://countryeconomy.com/gdp/france.

${ }^{3} \mathrm{http} / / /$ www.invest-in-france.org/medias/publications/223/aeros pace.
} 
revenue of US $\$ 59.3$ billion $^{4}$. Furthermore, Safran Group is the global leader in helicopter engines with revenues of US $\$ 18.54$ billion in $2013^{5}$ while Dassault Aviation is France's most important aerospace defense company with nearly US $\$ 5.4$ billion in revenues in $2012^{6}$. The company produces the Falcon, which is a highly popular business jet whose first model came out in the 1960s, and houses a space division producing mostly support equipment and some outer space planes, lines that also started in the $1960 \mathrm{~s}^{7}$. To sum up, few companies are in the same league as the major France-based aerospace enterprises, with the exception of the United States' Boeing and, to a much lesser extent, Canada's Bombardier.

Aerospace manufacturing is an important economic sector in Canada. The direct contribution of aerospace to the Canadian GDP is $1.85 \%$ which is larger than most other Canadian industrial sectors and a higher percentage than in other countries, but lower than the French figures mentioned above. The data compiled by the AIAC (Aerospace Industry Association of Canada) indicates that Canadian firms where aerospace is the main activity generated 22.8 billion \$CAN in revenues in 2012 . Nearly $80 \%$ of sales are exported including $54 \%$ to the United States in 2012. This level of exportation contributes to a consistent surplus in the industry, something that few Canadian industries can declare.

Although considerably smaller than Airbus and Boeing, Bombardier Aerospace is by far the largest aerospace company in Canada with $\$ 9.4$ million in aerospace revenues in $2013^{8}$. The company followed a growth strategy in the 1990s with the acquisition of Canadair, de Havilland, LearJet (Wishita) and Shorts Brothers (Belfast) making it the third largest aircraft

\footnotetext{
${ }^{4} \mathrm{http} / / /$ www.airbus-group.com/airbusgroup/int/en/news/press.2 0140226 airbus group annual press conference 2014.html.

${ }_{5}^{5} \mathrm{http}: / /$ www.safran-group.com/site-safran-en/finance-397/finan cial-publications/financial-press-releases/2013-935/.

${ }^{6} \mathrm{http}: / /$ www.dassault-aviation.com/wp-content/blogs.dir/2/files/ 2013/05/Rapport_financier_2012.pdf.

${ }^{7}$ http://www.dassault-aviation.com/en/.

${ }^{8} \mathrm{http} / / /$ ir.bombardier.com/modules/misc/documents/11/17/92/03

/14/Bombardier-FinancialReport-Fiscal-Year-2013-en.pdf.
}

maker. Bombardier Aerospace has been given credit for having invented the regional jet industry. However, it has conceded a growing share of this business segment to the very successful Brazilian company Embraer. If successful, Bombardier's new CSeries program could help the company keep its position as the third civil aerospace player. It should be noted, however, that this program is a risky proposition as the Canadian aircraft maker is now starting to compete with Airbus and Boeing.

Besides Bombardier, the Canadian aerospace industry counts a number of other important firms, such as Pratt \& Whitney, CAE, Magellan and Bell Helicopter Textron. Montreal, a city located in the province of Quebec, deserves the label of aerospace cluster as it is the only place in the world where all the components needed to assemble an aircraft are manufactured within a $30 \mathrm{~km}$ radius. Quebec and Ontario, two of the 10 Canadian provinces, account for $80 \%$ of aerospace employment, $50 \%$ and $30 \%$, respectively.

It should be noted that France and Canada are two rather different countries in terms of population density $^{9}$. It is therefore not surprising that France is home to a much larger number of aerospace groupings than Quebec and Canada.

\section{French Aerospace Landscape: Trade Associations, Clusters and Competitiveness Poles}

The strength of the French aerospace industry is seen by many actors as the result of the large number of industrial clusters and competitiveness poles that seem to have mushroomed in recent years. According to Matei [11], clusters and competitiveness poles have slightly different conceptual meanings, the former being closer to Marshallian industrial districts defined

\footnotetext{
${ }^{9}$ Whereas the territory of France covers $674,843 \mathrm{~km}^{2}$, the size of Canada is almost 15 times larger covering $9,984,670 \mathrm{~km}^{2}$. Quebec (one of Canada's 10 provinces) itself is more than twice bigger than France. Population density tells a different story with 97.5, 5.2 and 3.5 inhabitants per square kilometers in France, Canada, and Quebec, respectively.
} 
as an agglomeration of firms, mainly small entrepreneurial companies. Competitiveness poles are explicitly inspired by Porter's [12] diamond and are based on formalized linkages between local authorities, research organizations as well as large and small firms. Many of these groupings have developed in France since they started to gain popularity in the mid 2000s and a total of 71 of them can now be found ${ }^{10}$ across various industries such as emerging technology, automotive and aerospace ${ }^{11}$. Some of these groups now include hundreds of participating parties. Competitiveness poles are even formally defined in Article 24 of the French Finance Law as groupings of firms, universities, private and public research institutions in a given region with the objective to implement economic development projects that will favor innovation. The extent to which the large amount of public funding invested in these groupings genuinely adds value to the industry and benefits equally to all companies participating in them remains to be seen.

One of the longest standing trade organizations in France is the GIFAS (French Aerospace Industries Association). Founded in 1909, the organization counts 332 members ranging from major companies to small specialized organizations. This trade organization can be considered as a federation as it holds many fairly independent subcommittees such as GEAD (Aerospace and Defence Equipment Group), an organization focusing on equipment providers, or Aéro-PME, a committee focusing on the interest of small aerospace companies. GIFAS' membership spreads to all members of the aerospace sector, including but not limited to, civil and defense aircrafts, helicopters, engines, weapons, satellites and software applications. GIFAS claims that they have three goals: (1) to represent and coordinate; (2) to analyze trade interests; and (3) to promote and train. In other words, they claim

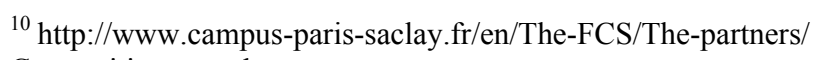
Competitiveness-clusters.

${ }^{11} \mathrm{http}: / /$ competitivite.gouv.fr/documents/commun/Documentati on_poles/brochures_poles/anglais/brochure-ang-internet.pdf.
}

to be the voice of the French aerospace industry. GIFAS also deals with aerospace organizations on the international scene and analyses regulations in order to make sure that they do not harm the French aerospace industry. Lastly, they participate in trade shows, put together exhibitions, spread information and organize the influential Paris air show. GIFAS also contributes to the training of the future industry workforce in universities, engineering schools and other aeronautic training programs ${ }^{12}$. With a long history and clear purpose, it can be argued that GIFAS occupies the center stage in the French aerospace industry and is highly legitimate.

The south-western part of France (particularly Bordeaux and Toulouse) is recognized as an aerospace hotbed. The region is home to major companies such as Airbus, Air France and Dassault Aviation, to several academic institutions and research centers, and to 260 SMEs (small and medium enterprises). Altogether, these varied and numerous organizations are known as “Aerospace Valley" and are credited for approximately 120,000 industry and 8,500 research positions. Since it was created in 2005, Aerospace Valley has allegedly initiated 220 research projects, using 204 million dollars of government funding ${ }^{13}$. Bringing together public funding, academia, and industry, Aerospace Valley appears like a perfect illustration of a competitive pole in which several projects involving firms and researchers have been initiated to improve industry practices and increase French aerospace performance. With 570 members in total, the 9-year old valley claims to be a fruitful and useful institution towards advancement of the French aerospace industry.

Another major competitiveness pole, called Pegase, is located just east of Aerospace Valley. Founded in 2006, the Pegase pole brings together 323 members including 180 SMEs, 13 engineering schools, 16 universities and eight world renowned companies

\footnotetext{
${ }^{12} \mathrm{https}: / / \mathrm{www}$. gifas.asso.fr/en/general-presentation

${ }^{13} \mathrm{http}: / / \mathrm{www}$.eacp-aero.eu/index.php?id=26.
} 
(including Thales, Dassault Aviation and Eurocopter). This aerospace grouping, like many others in France, is largely focused on regional promotion and research and development. Pegase's main focuses are surveillance, intervention, transport and communication and the pole includes 1,700 researchers in the region of Provence-Alpes-Cote-d'Azur. The region is also home to the Major National Center for Simulation which includes a $5 \mathrm{~km}$ runway (the longest in Europe) that is suited for American space shuttle emergency landings 14 . Pegase is largely supported by contributions from government and government-affiliated entities that amounted to over US $\$ 19.8$ million in $2010^{15}$. It should be noted that, like many other aerospace groupings, Pegase is dominated by large companies.

A third aerospace competitiveness pole, called ASTech Paris, is centered around Paris and brings together 500 members, including Airbus Group, Air France and Dassault Aviation. ASTech Paris claims to be responsible for over $90 \%$ of French business jets R\&D as well as most of the country's R\&D job creation. The pole focuses on business aviation, space travel, and motors and equipment for both aircraft and spacecraft $^{16}$. Founded in 2007, ASTech Paris has much in common with Aerospace Valley. One can wonder whether it is necessary to separate a rather small country into several regional poles of competitiveness instead of having all of the nation's companies cooperate. Although it is undeniable that the French aerospace industry is presently thriving, the creation of two major competitiveness poles relatively close to each other could favor rivalry, contradicting the whole rationale behind clustering.

The SPACE (supply chain process towards aeronautical community excellence) was put together

\footnotetext{
${ }^{14}$ http://www.investinpaca.com/files/PEGASE_A.pdf.

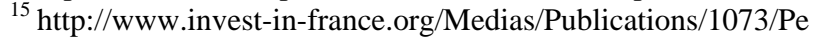
gase-french-innovation-cluster.pdf.

${ }^{16} \mathrm{http}: / /$ www.pole-astech.org/site/pages/index.php?lang=fr\&sec tion=pole.
}

by Airbus and Dassault Aviation among others in 2007. SPACE brings together 103 companies, most of which are part of more than one competitiveness pole or association. Interestingly, all of the 16 SPACE “executive members” are among the biggest aerospace companies in the country, as opposed to the "associate members", which are mostly small firms. SPACE claims that its aim is to "develop a common approach to improve the global risk management process” adding that "executive members dedicate their skilled resources to implement development action plans in common with suppliers" ${ }^{\text {17 }}$. It is very possible that such a structure provides higher bargaining power to larger companies and results in asymmetrical business relationships between large and small members. The "referral service" provided by SPACE, through which suppliers are recommended to OEMs, illustrates this. Three criteria are used when referring an aerospace supplier to a client: the use of a standard tool set, having minimum experience and offering a competitive price.

Located in the north of France, Normandie Aerospace, frequently referred to as NAE, defines itself as a "filière" (business sector) ${ }^{18}$. Whereas early meetings of its nine founding members took place in 1998, NAE literally erupted in 2012 when it went from 17 to more than 80 members. This organization is cluster-like in its desire to develop activities in Normandie to make sure that the region remains a competitive aerospace player and is able to attract talented individuals. This purpose seems different than the one of GIFAS, the French historic aerospace association. NAE argues that, to achieve their mission, they need to train individuals, use $R \& D$ projects to foster innovation, and help develop and promote companies in the area ${ }^{19}$. NAE does not enjoy as much academic participation and has a smaller membership than other aerospace groupings. As mentioned before, the large amount of French neighboring clusters and competitiveness poles which all benefit from public

\footnotetext{
${ }^{17}$ http://www.space-aero.org/what-is-space/\#.

${ }^{18} \mathrm{http}$ ://www.nae.fr/?lang=eng.

${ }^{19} \mathrm{http}: / / \mathrm{www} \cdot$.nae.fr/?lang=eng.
} 
funding is somewhat puzzling. The return on this public investment is not easily measurable and there is no guarantee that all members of a cluster receive equal treatment, whatever their sizes. There is also a potential risk that the associations (or poles) forming this rather thick institutional environment become self-serving and eventually exist more for themselves than for the members that they are supposed to represent and promote.

Bordering Normandy, Brittany also has its own aerospace companies and research centers, grouped in yet another cluster called IEF (Invest in Finistère) Aero $^{20}$ whose mission is virtually the same as NAE's. IEF is a smaller cluster founded in 2007 which comprised 28 companies and eight research centers. The smaller size of this cluster makes its status of a stand-alone organization especially questionable. Nevertheless, the support from GIFAS and several major industry players such as Thales and DCNS has enabled IEF to easily stay afloat.

\section{Canadian Aerospace Landscape: Trade Associations, Clusters and Consortiums}

Industrial clusters ("grappes industrielles”) are very popular in the province of Quebec, in which Montreal is located. Their popularity can be partly attributed to the effort of Gérald Tremblay, a Harvard business school MBA holder and Michael Porter follower, who was Minister of Industry in the early 1990s and Mayor of Montreal from 2001 to 2012. His enthusiasm for the concept of industrial clusters was very well reflected in the transcript of a speech that he gave during an international conference on innovation and business development [13]. Tremblay's talk explicitly referred to Porter's [14] clusters definition, namely the geographical concentration of firms and institutions in a particular domain, including suppliers and OEMs, as well as governmental agencies, universities, technical colleges and trade associations. He candidly claimed

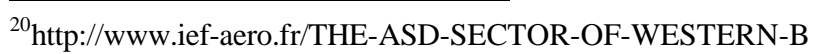
RITTANY-242-0-0-0.html. that he played a key role as minister of industry to "implement the Quebec industrial clusters strategy" which resulted in the following four competitive clusters in Montreal: aerospace, life sciences, information technologies and audiovisual production. These groupings share a close resemblance with the French competitiveness poles described above.

The image of a strong-willed political leader claiming to have put together various clusters is rather different than what is known about Italian industrial districts which have attracted attention since the end of the 1960s [15]. These districts, in fields such as textile, furniture and footwear (located respectively in Carpi and Prato, Brianza and Cascina, and in Vigevano) are characterized by a large sense of cooperation between competitive enterprises in order to share risks, stabilize the markets and share innovations [16]. Raveyre and Saglio [17] explain this cooperation by the existence "of commonly admitted rules that dictate behavior and model relations". Becattini [18] defines the Italian industrial district as "a socioterritorial entity" that underlies a system of cultural references shared by members. As will be discussed later, the extent to which such collaboration networks can be enacted by policy makers is debatable.

As mentioned above, aerospace was identified by Tremblay [13] as one of Montreal's four competitive clusters. Interestingly, this "cluster" was given the name of "Aéro Montréal." Aéro Montréal is a public-private partnership that was launched in May 2006 which defined itself as a "strategic think tank" that brings together "all the major decision makers in Quebec's aerospace sector, including companies, educational and research institutions, associations and unions” ${ }^{21}$. Although this is how Aéro Montréal describes itself, all of the major "decision makers" might not necessarily agree with this description. As a matter of fact, Aéro Montréal's mission does not appear as straightforward as the purpose of other interest groups or trade associations that will be

\footnotetext{
${ }^{21}$ http://www.aeromontreal.ca/who-we-are/.
} 
described below. The group's mission is detailed as follows in its web site: "Aéro Montréal's mission is to mobilize industry players around common goals and concerted actions to increase the cohesion and optimize competitiveness of Quebec's aerospace cluster. It aims to foster the growth and expansion of the cluster to ensure that it may continue to create wealth for Montreal, Quebec and Canada." Interestingly, this mission statement seems very much in line with the vision of the former industry minister Tremblay, and is in the purest Porter tradition. How this translates into concrete actions is less clear. Aéro Montréal has a predilection for working groups and has created such groups in six different areas: supply chain development, branding and promotion, innovation, human resources, defense and national security and commercialization and market development. The cluster is particularly proud of its Mach initiative which is "designed to enhance the supply chain management of aerospace industries in Quebec by attempting to link customers and suppliers through collaborative relationships" 22 . This initiative that is not unlike the six sigma color belts: Quebec aerospace suppliers go through a review process after which they are awarded a Mach 1, Mach 2 or Mach 3 label. Aéro Montréal claims the Mach initiative helps with closing a so-called "gap" in Quebec's aerospace supply chain, allowing suppliers to be potentially recognized as world-class players.

Aéro Montréal has a lot in common with the competitiveness poles observed in France and has signed collaborative agreements with several of them, although the concrete nature of these agreements is not always clear. Another important player is the AIAC (Aerospace Industries Association of Canada), headquartered in Ottawa, Canada's capital located in the province of Ontario. Founded more than 50 years ago, AIAC represents aerospace OEMs and suppliers across all 10 Canadian provinces. Like France's GIFAS, AIAC claims to be the "national voice of Canada's aerospace industry": "Our mission is to

\footnotetext{
${ }^{22} \mathrm{http}: / /$ www.aeromontreal.ca/mach-en/.
}

understand, build consensus and provide leadership on aerospace policy issues of interest to the industry. We also work to increase Canada's profile on the world stage by communicating our air and space accomplishments and by promoting Canadian aerospace companies in foreign markets" ${ }^{23}$. AIAC actively and sometimes successfully lobbies to make sure that aerospace and defense contracts awarded by the Canadian Government to American or European OEMs are designed in a way that ensures some benefits for deserving Canadian aerospace suppliers. Similar trade associations can be found in various Canadian provinces, such as the Aerospace Industry Association of British Columbia and the Manitoba Aerospace Association in Western Canada, as well as the Ontario Aerospace Council in Central Canada.

While the aerospace and defence industries are present in all Canadian provinces, with most of them having very active trade associations, only Toronto (Ontario) and Montreal (Quebec) are formally identified as traditional aerospace clusters given that a large number of medium-size and small aerospace suppliers have been developed around historical aerospace OEMs. Aircraft design, development and production have been an important part of the history of the Toronto area. DHC (De Havilland Canada), which eventually absorbed most Toronto-based historical aircraft companies to become the key aerospace player in Toronto, was incorporated in Ontario in 1928 as a subsidiary of the British de Havilland. While Toronto was closely associated with the beginning of aviation in Canada and eventually developed as an aerospace center, the Montreal aerospace sector was built on the region's traditional strength in transportation equipment engineering. The development of this strength can be traced to the 1840s, when the expansion of the port of Montreal played an important role in the city's economic development. The production of heavy equipment for the rail and maritime transportation industries was a significant

\footnotetext{
${ }^{23} \mathrm{http}: / /$ www.aiac.ca/about/mission-and-vision/.
} 
business activity in the early days of Montreal as an industrial center [19].

Quebec Aerospace SMEs used to be represented by the AQA (Quebec Aerospace Association).The mission of this grouping of 200 SMEs founded in 1997 was to "define and assess the challenges of the global aerospace industry and to help Quebec SMEs to be better positioned on international markets" ${ }^{\text {24 }}$. It should be noted that a tension between AQA and Aéro Montréal has developed after the latter was launched in 2006 as documented in a research report on the performance and practice of Canadian aerospace suppliers conducted for Industry Canada [20, 21]. Larger aerospace companies (Tier 1 and OEMs) interviewed seemed to enjoy the presence of Aéro Montreal and value the forum for exchange that it constitutes. However, SMEs that participated in the research felt that they did not really have a voice in Aéro Montréal. Interestingly, larger aerospace companies that were interviewed did not feel that they "fitted" in the AQA, which they considered as a SMEs trade association. One respondent from a larger company mentioned that he preferred to avoid AQA meetings as he felt that many attendants seemed to be there to canvass his company for contracts [20]. The tension between AQA and Aéro Montréal seems to have been recently resolved, as the former was recently absorbed by the latter.

Another grouping worth mentioning is the CRIAQ (Synergetic Research and Innovation in Aerospace) which is managed by six Quebec universities and six industrial partners including OEMs such as Bombardier Aerospace, Pratt \& Whitney, CAE and Bell Helicopter. CRIAQ was established in 2001 and is considered as the brainchild of two Quebec academic researchers who were then advocating for the need to promote research and innovation in "one of the most important economical segment of the province" as reported by Armellini et al. [22] who refer to CRIAQ as

\footnotetext{
${ }^{24} \mathrm{http} / / /$ www.aqta.ca/membres/ASSOCIATION_QUEBECOIS
} E_DE_L_AEROSPATIALE.html?ID=135. a "reference model" for the Brazilian aerospace industry. The consortium's objective is to make sure that academic research generates new concepts that are ready for commercialization into future aerospace products. Armellini et al. [22] argue that the success of CRIAQ results in the close interaction between governments, productive structures (i.e., manufacturing firms) and technical-scientific infrastructures. Whereas CRIAQ's projects have favored the development of new aerospace technology in fields such as vibro-acoustics and noise control and composites, some industry members do not see the research consortium in a very positive light: "my impression of CRIAQ is not that it's there to align industry and needs, I view it as a funnel to allow Bombardier to get heavily subsidized research and very talented people for their own purposes" [20]. This view is reflected by the negative aspects of the consortium identified by Armellini et al. [22]. "In order to be part of the consortium, a company is required to have formed an R\&D structure a priori. It is not part of CRIAQ's scope to aid SMEs in this organization, in case the company lacks an R\&D structure." This points to potential power asymmetry and tension in the Quebec aerospace industry between large OEMs and small SMEs. It could be argued that the absorption of AQA by Aéro Montréal is likely to further reduce the bargaining power of smaller aerospace players.

An interesting development has recently taken place on the wider Canadian aerospace scene with the launch of the CARIC (Consortium for Aerospace Research and Innovation in Canada), an AIAC's initiative ${ }^{25}$ which will replicate the CRIAQ model. As a matter of fact, the launch of CARIC was announced in April 2014 during CRIAQ's annual forum. Although Aéro Montréal claimed on its website to be "delighted" by the launch of yet another aerospace grouping ${ }^{26}$, one can

\footnotetext{
${ }^{25} \mathrm{http}: / /$ www.newswire.ca/en/story/1340903/the-consortium-for -aerospace-research-and-innovation-in-canada-caric-launches- $t$ oday.

${ }^{26} \mathrm{http}$ ://www.aeromontreal.ca/aero-montreal-se-rejouit-du-lance ment-du-consortium-en-aerospatiale-pour-la-recherche-et-linno vation-au-canada-caric/.
} 
wonder whether the consortium could be seen as a threat by the Montreal aerospace cluster. In fact, the larger number of aerospace groupings, both in France and in Quebec, could give rise to an unhealthy competitive behavior. Furthermore, there is a risk for these groupings to eventually become self-serving, to exist just for the sake of existing and maintaining the jobs of the individuals that they employ rather than to help their members.

\section{Discussions and Conclusions}

Our review of the France and Quebec aerospace scene has clearly demonstrated the efforts of policy makers to develop aerospace clusters and competitiveness poles, often with the direct investment of public funds. Their actions go beyond putting together conditions that would favor the organic agglomeration of aerospace firms. Policy makers are literally trying to create such agglomerations. Although several authors such as Matei [11] see considerable value in this approach, we argue that it has several limits. To some extent, policy makers and managers who "artificially" put together aerospace clusters are almost acting like gardeners who would pull on a flower to make it grow. These actors seem to forget that longevity is needed for fruitful trustworthy relationships to develop between firms. They also seem to forget that space is a cognitive referent: actors attribute values, representations, ways of doing things, stories and remembrances of successful and unsuccessful ventures (or event conflicts) to a specific geographic location. As a result, space intervenes throughout a process whereby actors construct their shared identity and sense of belonging. To avail oneself of a geographical location also means availing oneself of belonging to a social group which facilitates relationship development within the group [23]. This local identity construction is a very long process through which trust and solidarity are built and through which knowledge can eventually be shared. However, it is important to understand that a mere geographical proximity does not automatically translate in a close relationship. Geographical proximity creates the potential for a relationship, but for a potential relationship to develop, organizational proximity must also exist.

The various aerospace groupings that we have identified during our research are presented in Fig. 1, which suggests a potential relationship between the age of the organization and the extent to which the grouping is "organic" or "synthetic". Synthetic groupings [24] are those that have been put together as

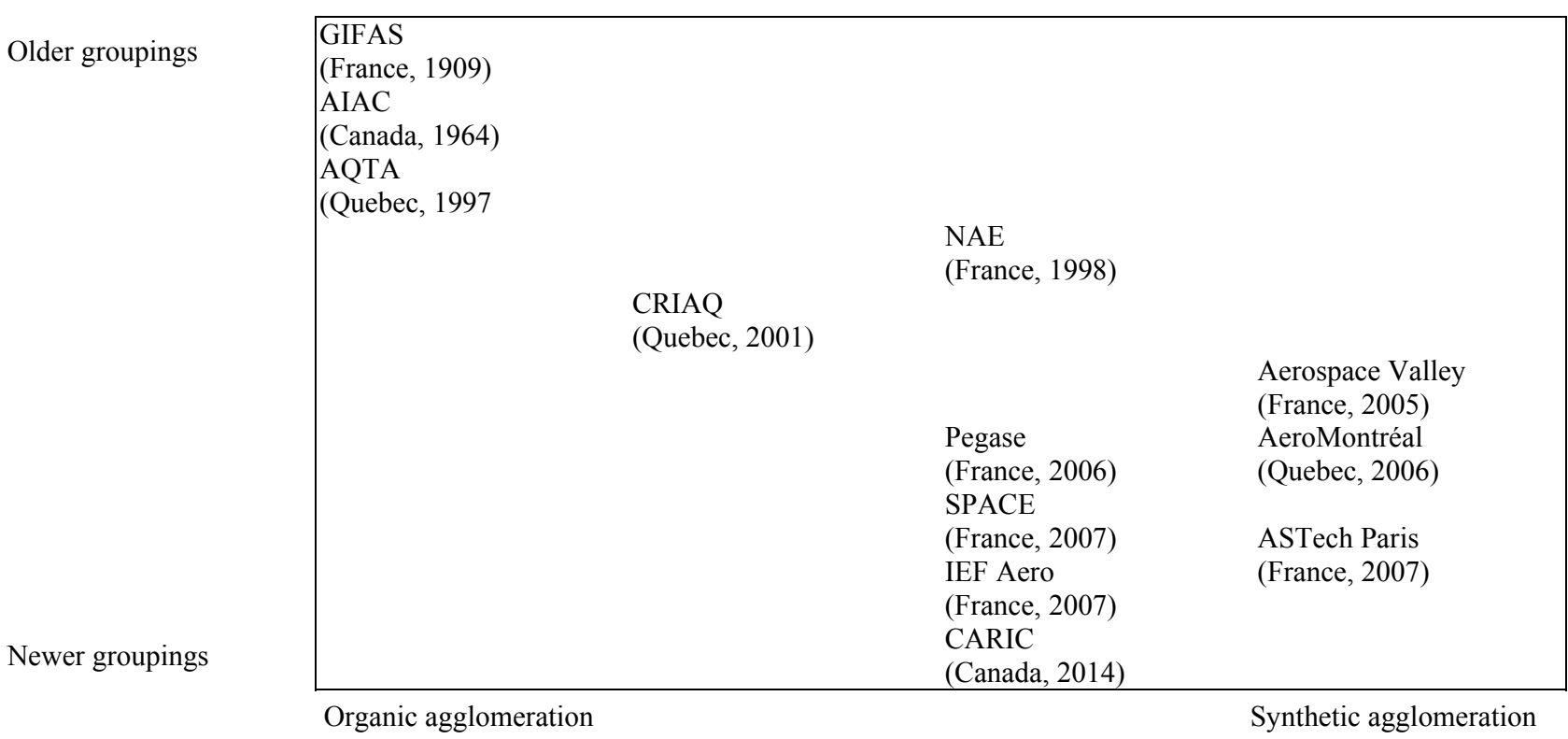

Fig. 1 Organic and synthetic aerospace groupings in France and Quebec. 
a result of direct governmental actions, whereas organic groupings are the result of industrial and/or academic aerospace stakeholders. We argue that clusters or firm agglomerations need to be developed organically instead of being enacted or invented by governments for social capital to develop. Artificially-created clusters are likely to benefit large players rather than small ones given their proximity to public power. Whereas small aerospace suppliers with limited manpower are often forced to complete long questionnaires in order to apply for public funding, large OEMs are good lobbyists who often only need to make a telephone call to obtain government support.

To some extent, through the enactment of aerospace clusters and competitiveness poles, policy makers seem to try to emulate Marshallian industrial districts. As mentioned earlier, Italian industrial districts are socio-territorial entities that underlie cultural references shared by the members of the district. These references are considered pre-existing historic and social material that serves as the basis of relationships characterized by confidence and reciprocity, as well as the construction of the non-economic interdependencies, found in Italian districts. Furthermore, industrial districts place the emphasis on the social embeddedness of economic relationships between firms [25]. The extent to which this process can happen as the result of policy is debatable.

Policy makers' objective in creating competitiveness poles was to promote and even create the development of interaction between players of the industry and members of superior education and research organizations, and to contribute to the growth of cognitive and technical heritage. Policy makers also wanted to diminish the risk of delocalization. In certain cases, poles have institutionalized pre-existing relationships. In other cases, they provided an opportunity to capture resources that the state promised to provide to companies. Thus, certain poles benefit from inter-organizational relationships. Others poles where the knowledge base was primarily industrial and had no history of science/industry cooperation did not benefit from such fruitful relationships. This raises the question of the extent to which policy makers can create or enact relationships between players in a given territory.

Furthermore, whether willful policy makers can create networks genuinely favoring the development of social capital and providing equal access to resources to all members remains to be seen. Therefore, the considerable amount of financial resources invested in so-called aerospace clusters and competitiveness poles might have such a significant impact on aerospace firms' financial and market performance. This is a question that should be addressed.

\section{Acknowledgments}

The authors wish to thank Thomas Beaucher, recipient of the CUSRA (Concordia Undergraduate Student Research Award) funded by Office of the Vice-President, Research and Graduate Studies, Concordia University for his help in the preparation of this paper.

\section{References}

[1] Niosi, J., and Zhegu, M. 2005. “Aerospace Clusters: Local or Global Knowledge Spillovers?." Industry and Innovation 12 (1): 5-29.

[2] Alfonso-Gil, J., and Vazquez-Barquero, A. 2010. "Networking and Innovation: Lessons from the Aeronautical Clusters of Madrid." International Journal of Technology Management 50 (3/4): 337-55.

[3] Storper, M. 1997. The Regional World: Territorial Development in a Global Economy. New York: Guilford Press.

[4] Porter, M. E. 1999. La Concurrence Selon Porter (Competition According to Porter). Paris: Village Mondial. (in French)

[5] Pecqueur, B. 1996. Dynamiques Territoriales et Mutations Economiques (Territorial Dynamic and Economic Mutations). Paris: Editions L'Harmattan. (in French)

[6] Storper, M. 1995. "The Resurgence of Regional Economies, Ten Years Later the Region as a Nexus of Untraded Interdependencies." European Urban and Regional Studies 2 (3): 191-221.

[7] Burt, R. S. 1992. Structural Holes: The Social Structure of 
Competition. Cambridge: Harvard University Press.

[8] Coleman, J. S. 1988. "Social Capital in the Creation of Human Capital." American Journal of Sociology 94: S95-S120.

[9] Nahapiet, J., and Ghoshal, S. 1998. "Social Capital, Intellectual Capital and the Organizational Advantage." Academy of Management Review 23 (2): 242-66.

[10] Emerson, D. 2012. Volume 1: Beyond the Horizon: Canada's Interests and Future in Aerospace-November 2012. Aerospace review report. Accessed June 13, 2014. http://aerospacereview.ca/eic/site/060.nsf/eng/00037.html.

[11] Matei R. M. 2013. "Creating Competitive Poles-The Sustainable Model for Obtaining the Competitive Advantage." Theoretical and Applied Economics 20 (8): 47-58.

[12] Porter, M. E. 1990. "The Competitive Advantage of Notions." Harvard Business Review 68 (2): 71-91.

[13] Thompson, J. D. 1967. Organizations in Actions. New York: MacGraw-Hill.

[14] Porter, M. E. 1998. "Clusters and the New Economics of Competition." Harvard Business Review 76 (6): 77-90.

[15] Sun, Y. 2012. Italian Industrial Districts: Recent Transformation and Innovation. Working papers series on European studies, Institute of European studies, Chinese Academy of Social Science.

[16] Benko, G., and Lipietz, A. 1992. Les Régions Qui Gagnent: Districts et Réseaux: Les Nouveaux Paradigmes de La Géographie Economique (Winning Regions: Districts and Networks: The New Paradigm of Economic Geography). Paris: France UniversityPress. (in French)

[17] Raveyre, M. F., and Saglio, J. 1984. "Les Systèmes Industriels Localisés: Eléments Pour une Analyse Sociologique des Ensembles de PME Industriels
(Localized Industrial Systems: A Sociological Analysis of SMEs Industrial Groupings)." Sociologie du Travail (Work Sociology) 2: 157-76. (in French)

[18] Becattini, G. 1992. "Le District Industriel: Milieu créAtif (Industrial District: A Creative Milieu)." Espaces et sociétés (Spaces and Societies) (1): 147-64. (in French)

[19] Germain, A., and Rose, D. 2000. Montréal: The Quest for a Metropolis. Chichester: John Wiley \& Sons.

[20] Dostaler, I. 2009. Global Value Chains: Aerospace Case Study. Research report prepared for Industry Canada.

[21] Dostaler, I. 2013. "Competing in the Global Aerospace Supply Chain: The case of the Canadian Aerospace Industry." Operations Management Research 6 (1): 32-43.

[22] Armellini, F., Kaminski, P. C., and Beaudry, C. 2011. "Consortium for Research and Innovation in Quebec-A Reference Model for the Brazilian Aerospace Industry." Product Management \& Development 9 (2): 101-9.

[23] Giddens, A. 1984. The Constitution of Society: Outline of the Theory of Structuration. Berkeley: University of California Press.

[24] Tremblay, G. 2008. "Les grappes et l'Innovation: Libérer le Capital Créatif (Clusters and Innovation: Freeing Creativity Capital)." Presented at Vingt et Unièmes Entretiens du Centre Jacques Cartier (Twenty-first Jacques Cartier Conference), Montreal, Canada. Accessed June 13, 2014. http://ville.montreal.qc.ca/pls/ portal/docs/page/librairie_fr/documents/EntretiensJC2008 2310.pdf. (in French)

[25] Powell, G. 1990. "One More Time: Do Male and Female Managers Differ?" Academy of Management Executive 4 (3): 68-75. 